\begin{abstract}
Iranica
Abstracta Iranica Revue bibliographique pour le domaine irano-aryen

Volume 34-35-36 | 2017

Comptes rendus des publications de 2011-2013
\end{abstract}

\title{
Christelle Jullien. Dans le royaume de Nemrod. Autour d'interprétations de Gn 10, 10-12
}

\section{Marie-Joseph Pierre}

\section{(2) OpenEdition}

1 Journals

\section{Édition électronique}

URL : http://journals.openedition.org/abstractairanica/41923

DOI : 10.4000/abstractairanica.41923

ISSN : 1961-960X

Éditeur :

CNRS (UMR 7528 Mondes iraniens et indiens), Éditions de l'IFRI

\section{Référence électronique}

Marie-Joseph Pierre, "Christelle Jullien. Dans le royaume de Nemrod. Autour d'interprétations de Gn 10, 10-12 », Abstracta Iranica [En ligne], Volume 34-35-36 | 2017, document 17, mis en ligne le 30 décembre 2016, consulté le 03 octobre 2020. URL : http://journals.openedition.org/abstractairanica/41923

DOI : https://doi.org/10.4000/abstractairanica.41923

Ce document a été généré automatiquement le 3 octobre 2020.

Tous droits réservés 


\title{
Christelle Jullien. Dans le royaume de Nemrod. Autour d'interprétations de Gn
} 10, 10-12

\author{
Marie-Joseph Pierre
}

\section{RÉFÉRENCE}

Christelle Jullien. « Dans le royaume de Nemrod. Autour d'interprétations de Gn 10, 10-12 », in : M. Loubet, D. Pralon, éds., Eukarpa. Études sur la Bible et ses exégètes en hommage à Gilles Dorival. Paris, 2011, p. 159-172.

1 L'énumération de plusieurs villes célèbres en Genèse 10, 10-12, dont la fondation est directement attribuée à Nemrod, a conduit des commentateurs juifs à proposer des identifications avec des cités du territoire iranien depuis Édesse jusqu'à Ctésiphon, ce dont quelques exégètes chrétiens syriaques se sont fait l'écho. Ce qui laisse à penser que ces villes pourraient faire partie d'une liste d'étapes des missions chrétiennes édesséniennes.

\section{AUTEURS}

\section{MARIE-JOSEPH PIERRE}

Directrice d'Études honoraire, EPHE 